\title{
Selection of the conveyor belt material for edible film production by a continuous casting process
}

\section{Seleção do material da esteira transportadora para produção de filme comestivel por processo de moldagem contínua}

\author{
Jimena Elizabeth Gamboni1* (1), María Verónica Colodro', Aníbal Marcelo Slavutsky, \\ María Alejandra Bertuzzi ${ }^{1}$
}

${ }^{1}$ Instituto de Investigaciones para la Industria Química (INIQUI-CONICET), Universidad Nacional de Salta, Facultad de Ingeniería, Salta - Argentina

*Corresponding Author: Jimena Elizabeth Gamboni, Instituto de Investigaciones para la Industria Química (INIQUI-CONICET), Universidad Nacional de Salta, Facultad de Ingeniería, Av. Bolivia 5150, A4408FVY, Salta -

Argentina, e-mail: jimenagamboni@gmail.com

Cite as: Gamboni, J. E., Colodro, M. V., Slavutsky, A. M., \& Bertuzzi, M. A. (2021). Selection of the conveyor belt material for edible film production by a continuous casting process. Brazilian Journal of Food Technology, 24, e2020026. https://doi.org/10.1590/1981-6723.02620

\begin{abstract}
The scaling up of the wet process and the design of a coating line to produce edible films, require the consideration of several factors such as, the film formulation, drying kinetics of the films, and the selection of a suitable support material in which to pour the solution. This work aimed to select the most suitable material for the construction of a conveyor belt for the fabrication of edible films through the wet process. The surface properties of the starch filmforming solution were determined. Several commercial materials for conveyor belts were tested. The film-forming solution spreadability and work of adhesion were determined. The mechanical behavior of the dry film was evaluated through mechanical properties and peeling resistance. All materials tested showed good performance under the operational conditions assayed to obtain edible films. Finally, the polyurethane band was chosen due to its appropriate performance and lower cost.
\end{abstract}

Keywords: Starch films; Spreadability; Work of adhesion; Solid surface tension; Scaling up; Coating line.

\section{Resumo}

O escalonamento do processo a úmido e o design de uma linha de revestimento para a produção de filmes comestíveis exigem a consideração de vários fatores, como a formulação do filme, a cinética de secagem dos filmes e a seleção de um material de suporte adequado no qual será despejada a solução. $O$ objetivo deste trabalho foi selecionar o material mais adequado para a esteira transportadora, a fim de construir equipamentos para a fabricação de filmes comestíveis através do processo a úmido. As propriedades da superfície da solução filmogênica de amido foram determinadas. Vários materiais comerciais para esteira transportadora foram testados. A dispersibilidade da solução filmogênica e o trabalho de adesão foram determinados. O comportamento mecânico do filme seco foi avaliado por meio das propriedades mecânicas e da resistência ao destacamento. Todos os 
materiais testados apresentaram bom desempenho nas condições operacionais testadas para obtenção de filmes comestíveis. Finalmente, a esteira de poliuretano foi escolhida devido ao seu desempenho adequado e menor custo.

Palavras-chave: Filmes de amido; Dispensabilidade; Trabalho de adesão; Tensão superficial sólida; Escalonamento; Linha de revestimento.

\section{Introduction}

Environmental concern demands reduction of the impact caused by plastic waste and the use of sustainable alternatives. One of the biggest applications for plastics is packaging, and along with new consumer habits and lifestyle, it is in continuous growth. In recent decades, the development of biodegradable/edible films has become an alternative to cope with environmental impacts (Alavi et al., 2014; Ebnesajjad, 2012). Large progress has been achieved in studying and developing biopolymeric based films. However, most of these developments remain in laboratory scale. Thus, large scale film production is required to make these edible films available to all the potential applications assessed.

Biopolymer films are basically obtained from a liquid phase, melt, or solution, which after a certain process turns into a solid phase. There are two main general processes, the wet process or casting, and the dry process. The former method consists of pouring a polymer solution onto a substrate followed by drying of the solvent. The latter method is based on the thermoplastic properties that some biopolymers exhibit, such as the extrusion process (Bertuzzi \& Slavutsky, 2016; Embuscado et al., 2009; Guilbert \& Gontard, 2005).

The production of edible films by dry methods means productivity and cost-effectiveness. However, considering the severe processing conditions required to transform biopolymers into thermoplastic materials, the properties of some of the components, especially active ones, may be affected. Thus, the wet processes can provide moderate and versatile way for manufacturing edible films, even considering that is a high energy-consuming procedure (Mellinas et al., 2016).

The wet method, commonly known as casting, consists of four basic steps: the elaboration of the filmforming solution, casting of the solution on an adequate supporting material or substrate, drying, and finally, detachment of the film from the surface. Taking this into consideration, the wet method is a coating operation, and as such pre-existing technologies can be adapted to the production of biopolymeric films (Bertuzzi \& Slavutsky, 2016; Mellinas et al., 2016). Among several technologies available for thin films and coatings, the most employed ones are casting on steel belt conveyors and casting on disposable substrates (Embuscado et al., 2009). A typical coating line consists of the equipment for solution preparation and the coating machine line itself. The equipment for solution preparation is a separate batch operation and includes a thermostated vessel provided with mixing and feeding systems. On the other hand, the coating line is formed by a coating applicator, a conveyor belt and a conveyor belt transport system that takes the coated line through the drying chamber (Gutoff \& Cohen, 2016) as shown in Figure 1.

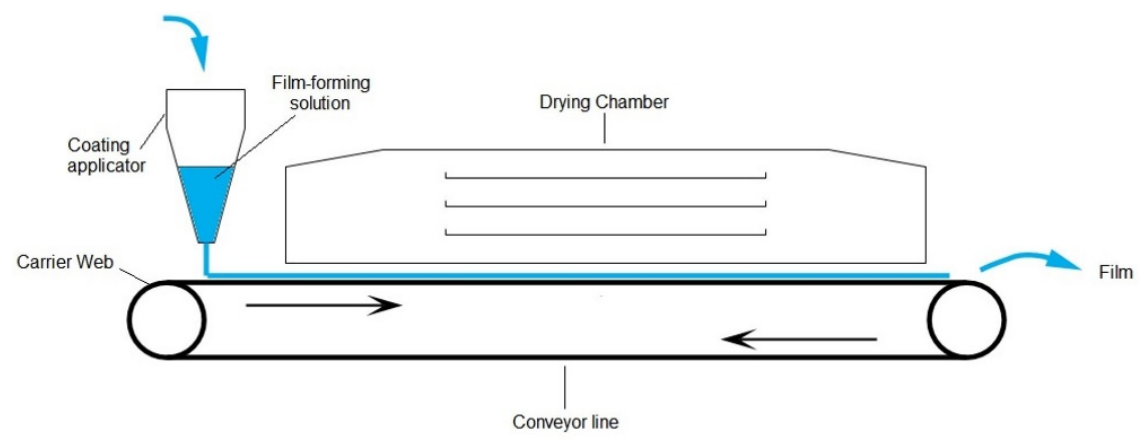

Figure 1. Schematic diagram of the casting technique. 
When scaling up the wet process and designing a coating line to produce edible films, many factors must be considered. As a general approach, the film formulation must be established, the drying kinetics of the films must be studied, and a suitable support material, where pouring the solution must be carefully selected. The correct selection of the substrate plays an important role in the casting process. The understanding of interactions between the substrate and the film-forming solution, and later the dry film, is crucial for a successful operation. On a laboratory scale, different materials have been employed as substrates, such as polystyrene, polyethylene, polycarbonate, glass, stainless steel, silicone, and polytetrafluoroethylene (PTFE, Teflon $^{\circledR}$ ) (Mellinas et al., 2016). The most common materials reported for conveyor belts on coating lines are polyester films or coated release paper (Embuscado et al., 2009). Therefore, the pouring of the solution directly on the surface of the conveyor belt surface and the variables associated with this stage are fundamental in the design of the industrial process. It allows achieving a uniform spread and an efficient drying and prevents the employment of a separate disposable substrate over the conveyor belt.

A suitable conveyor belt must be chemically, physically, and mechanically stable for processing purposes. It must be inert, capable to work under the drying temperatures and the mechanical stresses of the conveyor belt system. Chemical interactions shall not exist between the conveyor belt and the film-forming solution and its properties must remain constant. It must be stiff enough but flexible as well, to keep its dimensions during the application, transport, drying and wrapping around the transport rolls. Besides, the cost of the conveyor belt must also be an important factor to be considered (Bierwagen, 1992; Gutoff \& Cohen, 2016).

As previously stated, surface interactions between the substrate and the film-forming solution, the substrate and the film must be studied to select a proper material that guarantees a correct coating performance. The wettability and adhesion parameters are of great importance. The film-forming solution should have a shear-thinning behavior, it must be able to wet completely and spread uniformly over the substrate or the conveyor belt surface without pouring out. Furthermore, the film should remain attached to the conveyor belt until it must be separated and should be easily detached from the conveyor belt when it is finally dried (Bierwagen, 1992; Embuscado et al., 2009; Gutoff \& Cohen, 2016).

This work aimed to select the most suitable material for the conveyor belt for the construction of equipment for film formation with casting process. The surface properties of the film forming solution were determined and its spreadability over different commercial materials was determined. Furthermore, the adhesion of the dry films on the surfaces was evaluated.

\section{Materials and methods}

\subsection{Materials}

Edible films were prepared using native corn starch (Unilever, Argentina). Glycerol (Biopack, Argentina) was used as plasticizer. Ultrapure water (UP water), formamide (Sigma Aldrich, Argentina), and dimethylsulfoxide (Sigma Aldrich, Argentina) were used as test liquids.

The selected materials correspond to commercial conveyor belts suitable for food use, detailed in Table 1.

\subsection{Film forming solution}

The film-forming solution was prepared by dispersing $5 \mathrm{~g}$ of food-grade corn starch with glycerol, in a concentration of $20 \% \mathrm{w} / \mathrm{w}$ of starch, as a plasticizer in $100 \mathrm{~mL}$ of distillate water. The dispersion was gelatinized at $85^{\circ} \mathrm{C}$ for 15 minutes under constant mixing, to guarantee the disintegration of starch granules and to obtain a homogeneous solution. 
Table 1. Commercial materials for conveyor belts.

\begin{tabular}{|c|c|c|c|}
\hline $\begin{array}{l}\text { Commercial } \\
\text { Name }\end{array}$ & Brand and origin & Material & Additional features* \\
\hline Stainless steel & Famiq, Argentina & Stainless steel AISI 430 & Thickness: $0.5 \mathrm{~mm}$ \\
\hline Aluminum & $\begin{array}{c}\text { Multibujes Metales, } \\
\text { Argentina }\end{array}$ & Aluminum alloy & Thickness: $0.5 \mathrm{~mm}$ \\
\hline Sanitary rubber & Heipon, Argentina & $\begin{array}{l}\text { Acrylonitrile-copolymer } \\
\text { butadiene }\end{array}$ & $\begin{array}{l}\text { Thickness: } 5 \mathrm{~mm} \\
\text { Rough and porous surface }\end{array}$ \\
\hline VERNA 1206 & SIME, Argentina & Silicone & $\begin{array}{c}\text { Internal polyester mesh, Intermediate } \\
\text { polyurethane layer and a silicone top layer. } \\
\text { Thickness: } 1.40 \mathrm{~mm} \\
\text { Smooth, opaque surface }\end{array}$ \\
\hline VERNA 12SCF & SIME, Argentina & Silicone & $\begin{array}{c}\text { Internal polyester mesh, intermediate PVC } \\
\text { layer and a silicone top layer. } \\
\text { Thickness of } 1.75 \mathrm{~mm} . \\
\text { Smooth, bright surface. Antistatic }\end{array}$ \\
\hline CLINA 12UF & SIME, Argentina & Polyurethane & $\begin{array}{c}\text { Internal polyester mesh, intermediate PVC } \\
\text { layer, superior polyurethane covering } \\
\text { Thickness: } 1.60 \mathrm{~mm} \\
\text { Smooth surface }\end{array}$ \\
\hline TAC SIL 24 & Taconic, Argentina & Silicone & $\begin{array}{c}\text { Polyester mesh impregnated with silicone } \\
\text { Thickness: } 500 \mu \mathrm{m} \\
\text { Rough surface }\end{array}$ \\
\hline TAC 36 & Taconic, Argentina & $\begin{array}{l}\text { Poly-tetrafluoroethylene } \\
\text { (PTFE) on glass fiber }\end{array}$ & $\begin{array}{c}\text { Fiberglass mesh impregnated in PTFE } \\
\text { Thickness: } 360 \mu \mathrm{m} .\end{array}$ \\
\hline
\end{tabular}

*Additional features are provided by manufacturer.

\subsection{Characterizations}

To select the proper material for the conveyor belt, the analyses were divided into two parts. The first part involved the understanding of the interaction between the conveyor belt material and the film-forming solution, and the second part the study of the interaction between the dry film and the belt material. The surface properties of the starch solution and the different support materials were studied. The mechanical behavior of the dried film was assessed: mechanical properties and peeling strength were evaluated.

\subsubsection{Surface properties}

Adhesion is a multidisciplinary phenomenon that includes surface chemistry, rheology, polymer chemistry, and mechanics of materials.

The adhesion between a liquid and a surface is due to the attractive or repulsive forces acting in the atoms and molecules of each material at the surfaces in contact. These interactions are governed by the surface energy of the systems. According to the thermodynamic theory of adhesion, when a liquid 
of known surface tension is in static equilibrium with a solid surface, the relationship between the surface tensions is (Equation 1):

$\gamma_{S}=\gamma_{S L}+\gamma_{L} \cos \theta$

Where $\gamma_{S}$ is the surface tension of the solid substrate, $\gamma_{\mathrm{L}}$ is the surface tension of the liquid and $\gamma_{\mathrm{SL}}$ is the interfacial tension between the liquid and solid, and $\theta$ is the contact angle formed between the liquid and the solid phase. When the attractive forces between different phases (adhesive forces) are greater than the attractive forces between molecules (cohesive forces) of the same phase, the affinity of the phases increases. Thus, the spreading of a liquid is provided by adhesion forces, while cohesion forces promote the contraction of the liquid. The wettability of a solution depends on the interaction of those forces and can be determined by calculating the spreading coefficient (Ws), the work of adhesion (Wa), and the work of cohesion (Wc), as the following equations indicate:

$W_{a}=\gamma_{L}+\gamma_{S}-\gamma_{S L}=\gamma_{L}(1+\cos \theta)$

$W_{C}=2 \gamma_{L}$

$W_{S}=W_{a}-W_{C}$

According to Zisman (1964) the work of adhesion can also be calculated by determining the contact angle of a liquid on a surface (Equation 5).

$W_{a}=\gamma_{L}(1+\cos \theta)$

On the other hand, the Acid-base theory, the Van Oss's Chaudhury, and Good theory (Van Oss et al., 1988) state that surface energy is composed of two parts (Equation 6):

$\gamma_{L}=\gamma^{L W}+\gamma^{A B}$

Where $\gamma^{L W}$ is the Lifshitz-van der Waals component or dispersed component and $\gamma^{A B}$ is the Lewis acidbase component or polar component. $\gamma^{L W}$ considers the London forces and dipole-dipole interactions, while the $\gamma^{A B}$ component takes into account hydrogen bonds.

According to this model, the polar component can be determined according to Equation 7 :

$\gamma^{A B}=2 \sqrt{\gamma^{+} \gamma^{-}}$

Where $\gamma^{-}$and $\gamma^{+}$correspond to Lewis-base and Lewis-acid parameters respectively, which conform the polar component. A material will be considered apolar if both components are close to zero, monopolar if either of them is negligible and bipolar if both values are considerable.

Therefore, Equation 5 can be rewritten as follows:

$W_{a}=2 \sqrt{\gamma_{L V}^{L W} \gamma_{S V}^{L W}}+2 \sqrt{\gamma_{L V}^{+} \gamma_{S V}^{-}}+2 \sqrt{\gamma_{L V}^{-} \gamma_{S V}^{+}}$

Equation 8 presents three unknown parameters: $\gamma_{S V}^{L W}, \gamma_{S V}^{+}, \gamma_{S V}^{-}$. If three liquids with known dispersed and acidbase components are used, a system of linear equations can be constructed as follows (Equation 9):

$\gamma_{L V, i}+\left(1+\cos \theta_{i}\right)=2 \sqrt{\gamma_{L V, i}^{L W} \gamma_{S V}^{L W}}+2 \sqrt{\gamma_{L V, i}^{+} \gamma_{S V}^{-}}+2 \sqrt{\gamma_{L V, i}^{-} \gamma_{S V}^{+}}$

This system of equations can be written in matrix form:

$A x=B$

$A=\left|\begin{array}{lll}\sqrt{\gamma_{L V, 1}^{L W}} & \sqrt{\gamma_{L V, 1}^{+}} & \sqrt{\gamma_{L V, 1}^{-}} \\ \sqrt{\gamma_{L V, 2}^{L W}} & \sqrt{\gamma_{L V, 2}^{+}} & \sqrt{\gamma_{L V, 2}^{-}} \\ \sqrt{\gamma_{L V, 3}^{L W}} & \sqrt{\gamma_{L V, 3}^{+}} & \sqrt{\gamma_{L V, 3}^{-}}\end{array}\right|$ 
$B=\left|\begin{array}{l}\gamma_{L V, l}+\frac{\left(1+\cos \theta_{l}\right)}{2} \\ \gamma_{L V, 2}+\frac{\left(1+\cos \theta_{2}\right)}{2} \\ \gamma_{L V, 3}+\frac{\left(1+\cos \theta_{3}\right)}{2}\end{array}\right|$
$x=\left|\begin{array}{l}\sqrt{\gamma_{S V}^{L W}} \\ \sqrt{\gamma_{S V}^{-}} \\ \sqrt{\gamma_{S V}^{+}}\end{array}\right|$

This system of equations, in general, is conditioned and small differences in the data or coefficients can induce strong variations in the results (Della Volpe \& Siboni, 1997). Therefore, test liquids should be chosen in such manner that the condition number of the matrix is low. In general, this can be achieved with a set of liquids in which there is a prevalence of dispersive character, that is, acid and basic character.

Support surfaces were cleaned before the measurement of contact angles. Samples were submerged in a detergent bath, rinsed with tap water, then with distillate water, and finally with ethanol. The samples were dried for 15 minutes.

\subsubsection{Wettability of starch solution}

The wettability of starch solution over the different supports was determined by measuring the work of adhesion, work of cohesion, and spreadability coefficient. According to Equations 2 to 4, the liquid surface tension and the contact angle must be experimentally determined.

Measurements of the contact angles were performed by the sessile drop method at room temperature, using a goniometer (Standard Goniometer with DROP image standard, model 200-00, Rame-Hart Instrument Co., Succasunna, USA).

The starch solution surface tension was determined by the du Noüy ring method. This method consists of lifting a platinum-iridium ring from a liquid surface. The force $(\mathrm{F})$ required to raise the ring from the liquid surface is measured and related to the surface tension of the liquid (Equation 14).

$F=f \cdot \gamma_{L} \cdot 4 \cdot \pi \cdot r$

Where $\mathrm{f}$ is correction factor and $\mathrm{r}$ is the radius of the ring in $\mathrm{cm}$. The tensiometer provides the surface tension in dyne $\mathrm{cm}^{-1}$. Starch solution surface tension was determined at $25{ }^{\circ} \mathrm{C}$ and as a mean result of ten measurements. Surface tension of distillate water was also determined to calculate the correction factor. The surface tension obtained experimentally $\left(\gamma_{\mathrm{H} 2 \mathrm{O}} \exp \right)$ was compared to the literature value $\left(\gamma_{\mathrm{H} 2 \mathrm{O}}=72.8 \mathrm{mN} \mathrm{m}^{-1}\right)$. Finally, the correction factor was calculated by Equation 15.

$$
f=\frac{\gamma_{H 2 O T a b}}{\gamma_{H 2 O}}
$$

\subsubsection{Surface tension of test materials}

The surface tension of the support materials was determined by employing the test liquids listed in Table 2 .

Table 2. Surface tension of pure liquids ${ }^{\mathrm{a}}$.

\begin{tabular}{cccc}
\hline & UP Water & Formamide & Dimethylsulfoxide \\
\hline$\gamma_{\mathrm{L}}(\mathrm{mN} / \mathrm{m})$ & 72.2 & 58 & 44 \\
\hline$\gamma_{\mathrm{L}}{ }^{\mathrm{LW}}(\mathrm{mN} / \mathrm{m})$ & 21.2 & 39 & 36 \\
\hline$\gamma_{\mathrm{L}}{ }^{+}(\mathrm{mN} / \mathrm{m})$ & 25.5 & 2.28 & 0.5 \\
\hline$\gamma_{\mathrm{L}}{ }^{-}(\mathrm{mN} / \mathrm{m})$ & 25.5 & 39.6 & 32 \\
\hline
\end{tabular}

a Data were extracted from (Della Volpe \& Siboni, 1997). 
The contact angles of the test liquids for each material studied were measured and using Equations 10 to 13 , the surface energies were determined. The study was conducted at $25^{\circ} \mathrm{C}$ and ten measurements were made for each test liquid.

\subsubsection{Mechanical properties}

Mechanical tests were performed on the starch films using a texturometer Brookfield (Massachusetts, USA). Tensile strength and tear resistance properties of starch films were assessed. Peel strength between the support material and the starch film was determined. The texturometer was placed in a chamber where the environmental conditions (temperature and $\% \mathrm{RH}$ ) were controlled. The tests were performed with at least five samples.

To analyze tensile properties and tear resistance the film-forming solution was cast onto plastic dishes. After drying, the films were peeled off. To obtain the test samples for the peel strength analysis, the film forming solution was cast over samples of the different supports of $25 \mathrm{~mm}$ width and $355 \mathrm{~mm}$ length. In this assay, after drying, the films were not peeled off from the supports. Dishes and test samples were placed in an air-circulating oven at $30^{\circ} \mathrm{C}$ until films were dried. Finally, all the samples were kept at $53 \% \mathrm{RH}$ and $25{ }^{\circ} \mathrm{C}$ for a week.

To determine the strength of adhesive bonds between the film and the support material, adhesive peel strength test, at 180-degree angle, was performed according to ASTM D903 (American Society for Testing and Materials, 2010a). Peak load and average load were determined. The peel strength data were recorded along $100 \mathrm{~mm}$ of the sample with a velocity of $20 \mathrm{~mm} \mathrm{~m}^{-1}$.

We obtained tensile properties and tear resistance with the purpose of comparing adhesive forces of the films to the supports with internal cohesive forces of the film. The tear resistance test measures the force per unit thickness required to rupture and to propagate a tear through the film. The test was performed as indicated by the method ISO 6383 (International Organization for Standardization, 2004). The samples were cut like trousers of $150 \mathrm{~mm}$ length and $40 \mathrm{~mm}$ width. Tear force was recorded up to break.

The tensile properties were determined according to ASTM D882 (American Society for Testing and Materials, 2010b). The films were cut into strips of $25 \mathrm{~mm}$ wide and $80.0 \mathrm{~mm}$ long. The exposed film area was $25 \mathrm{~mm}$ x $60 \mathrm{~mm}$. Elongation at break (\%E) and tensile strength (TS) were calculated by Equations 16 and 17.

$$
\begin{aligned}
& T S=\frac{\text { Maximum } \operatorname{Load}(N)}{\text { Maximum cross sectional area }\left(m^{2}\right)} \\
& \% L=\frac{L_{f}-L_{i}}{L_{i}} 100 \%
\end{aligned}
$$

Where $\mathrm{L}_{\mathrm{i}}$ is the initial gage length of the specimen and $\mathrm{L}_{\mathrm{f}}$ is extension at the moment of rupture of the specimen.

\subsubsection{Statistical analysis}

Analyses of variance (ANOVA) were employed to analyze the data using Graphpad Prism (Version 5.01, California, USA) software. Differences between the mean values of the measured properties were compared using a multiple-range Tukey's test. A significance level of 0.05 was used.

\section{Results and discussion}

The interactions between the films and the different supports were analyzed through three assays. The first assay consisted of the casting of the solution over the support materials: the surface properties were studied 
to determine whether the spreadability was optimal. The second test consisted of the detachment of the film from the supports. The film adhesion to the support must be strong enough to keep the film over the surface but loose enough to be released: peeling strength was assessed. Finally, when the film was already detached, mechanical resistance was evaluated to compare adhesive forces and cohesive forces.

\subsection{Surface properties}

The surface tension of the starch solution was determined using the Du Nouy ring method. The mean value obtained for ten measurements was $67.05 \pm 0.78 \mathrm{mN} \mathrm{m}^{-1}$.

On the other hand, Table 3 shows the values of the contact angles formed by the film-forming solution on the different support materials and the values of the work of adhesion and the spreading coefficient.

Table 3. Contac angles, work of adhesion and spreading coefficient of the starch solution on the different support materials.

\begin{tabular}{llll}
\hline Material & $\boldsymbol{\theta}\left({ }^{\circ}\right)$ & $\mathbf{W}_{\mathbf{a}}(\mathbf{m N} / \mathbf{m})$ & $\mathbf{W}_{\mathbf{s}}(\mathbf{m N} / \mathbf{m})$ \\
\hline Steel & $76.68 \pm 1.69^{\mathrm{a}}$ & $82.50 \pm 0.96^{\mathrm{a}}$ & $-51.60 \pm 2.52^{\mathrm{a}}$ \\
\hline Aluminum & $76.24 \pm 2.39^{\mathrm{a}}$ & $83.00 \pm 1.75^{\mathrm{a}}$ & $-51.10 \pm 3.30^{\mathrm{a}}$ \\
\hline Sanitary rubber & $73.93 \pm 1.68^{\mathrm{b}}$ & $85.61 \pm 0.89^{\mathrm{b}}$ & $-48.49 \pm 2.45^{\mathrm{b}}$ \\
\hline VERNA 1206 (silicone) & $96.26 \pm 1.85^{\mathrm{c}}$ & $59.74 \pm 1.45^{\mathrm{c}}$ & $-74.36 \pm 3.01^{\mathrm{c}}$ \\
\hline VERNA 12SCF (silicone) & $96.68 \pm 0.85^{\mathrm{c}}$ & $59.25 \pm 0.30^{\mathrm{c}}$ & $-74.85 \pm 1.86^{\mathrm{c}}$ \\
\hline CLINA 12UF (Polyurethane) & $80.52 \pm 1.10^{\mathrm{d}}$ & $78.09 \pm 0.36^{\mathrm{d}}$ & $-56.01 \pm 1.90^{\mathrm{d}}$ \\
\hline TAC SIL 24 (silicone) & $79.98 \pm 1.25^{\mathrm{d}}$ & $78.92 \pm 0.52^{\mathrm{d}}$ & $-55.18 \pm 2.01^{\mathrm{d}}$ \\
\hline TAC 36 (PTFE) & $103.4 \pm 1.87^{\mathrm{e}}$ & $51.51 \pm 1.53^{\mathrm{e}}$ & $-82.59 \pm 3.01^{\mathrm{e}}$ \\
\hline
\end{tabular}

The same letters indicate no significant difference $(p<0.05) . \theta$ is the contact angle formed between the liquid and the solid phase; $\mathrm{W}_{\mathrm{s}}$ is the spreading coefficient, $\mathrm{W}_{\mathrm{a}}$ is the work of adhesion, $\mathrm{W}_{\mathrm{c}}$ is the work of cohesion.

We observed that the metal surfaces presented low contact angle values and therefore, greater wettability and greater adhesion strength. Furthermore, the sanitary rubber showed similar behavior, presenting the greatest work of adhesion and the highest spreading coefficient. The silicone supports presented lower values of work of adhesion, and the PTFE material (TAC 36) had the least value of work of adhesion among all the materials assayed.

A liquid is more suitable to cover a surface when the spreadability coefficient (Ws) takes values closer to zero. At this stage, steel, aluminum, sanitary rubber, CLINA 12UF, and TAC SIL 24 would make suitable support materials for the conveyor belt.

The surface energy of the different support materials was determined according to the theory of Van Oss et al. (1988). Although the use of this method is simple, the results should be considered at a comparative level. The results obtained by these methods depend on contact angle measurements and are strongly dependent on the choice of test liquids; if standardized methods and test liquids are not established, the values obtained are only of comparative value (Della Volpe \& Siboni, 1997; Rudawska \& Jacniacka, 2018).

The values of the contact angles obtained with the test liquids on the different supports and the calculated value of the surface energy for each solid are reported in Table 4. According to Zisman (1964), polymeric materials correspond to low energy systems, $\gamma_{\mathbf{S V}}<100 \mathrm{mN} / \mathrm{m}$, while metals are high energy surfaces. There are numerous limitations with respect to the determination of the surface energy of solids by different methods, since they depend on different factors, such as the effect of surface roughness, test temperature, conditions of each surface, and precision of contact angle measurement. Therefore, it is rather complicated to compare our data with the results published in similar studies. However, the surface energy values obtained for the polymeric materials are in accordance with the ranges of values reported in the literature for different polymeric materials: between 25 and $45 \mathrm{mN} / \mathrm{m}$ (Pisanova \& Máder, 2000). For example, Erbil \& Meriç 
(1988) reported values of $30.6 \mathrm{mN} / \mathrm{m}$ for polyethylene, $32.8 \mathrm{mN} / \mathrm{m}$ for ethylene vinyl acetate, and $42.7 \mathrm{mN} / \mathrm{m}$ for ethylene vinyl alcohol. Skurtys et al. (2011) reported a value of $20.5 \mathrm{mN} / \mathrm{m}$ for polytetrafluoroethylene (PTFE) and $41.5 \mathrm{mN} / \mathrm{m}$ for polystyrene.

Table 4. Contact angles and solid surface energy on the different supports.

\begin{tabular}{|c|c|c|c|c|}
\hline \multirow{2}{*}{ Material } & \multicolumn{3}{|c|}{ Contact angles } & \multirow{2}{*}{$\gamma_{\mathrm{SV}}(\mathrm{mN} / \mathrm{m})$} \\
\hline & UP Water & Formamide & Dimethylsulfoxide & \\
\hline Steel & $84.87 \pm 2.13^{\mathrm{a}}$ & $72.89 \pm 2.03^{\mathrm{a}}$ & $47.31 \pm 1.34^{\mathrm{a}}$ & 272.87 \\
\hline Aluminum & $84.54 \pm 3.22^{\mathrm{a}}$ & $73.38 \pm 1.21^{\mathrm{a}}$ & $49.22 \pm 1.53^{\mathrm{a}}$ & 245.39 \\
\hline Sanitary rubber & $70.02 \pm 3.17^{\mathrm{b}}$ & $68.94 \pm 1.55^{\mathrm{b}}$ & $56.32 \pm 2.51^{\mathrm{b}}$ & 26.41 \\
\hline VERNA 1206 & $92.19 \pm 2.06^{\mathrm{c}}$ & $89.42 \pm 2.31^{\mathrm{c}}$ & $81.41 \pm 1.06^{\mathrm{c}}$ & 15.08 \\
\hline VERNA 2SCF & $95.16 \pm 2.81^{\mathrm{c}}$ & $90.30 \pm 0.99^{c}$ & $80.31 \pm 0.88^{c}$ & 20.49 \\
\hline CLINA 12UF & $93.40 \pm 2.72^{\mathrm{c}}$ & $73.87 \pm 0.98^{\mathrm{a}}$ & $56.21 \pm 2.15^{\mathrm{b}}$ & 26.49 \\
\hline TAC SIL 24 & $93.78 \pm 2.32^{\mathrm{c}}$ & $87.27 \pm 1.93^{\mathrm{d}}$ & $82.01 \pm 0.92^{\mathrm{c}}$ & 32.59 \\
\hline TAC 36 & $102.39 \pm 1.79^{\mathrm{d}}$ & $88.29 \pm 1.33^{\mathrm{d}}$ & $75.03 \pm 1.23^{\mathrm{d}}$ & 24.09 \\
\hline
\end{tabular}

The same letters at the same column indicate no significant difference $(p<0.05)$.

The spreading of a liquid over a surface is considered spontaneous when $\gamma_{\text {solid }} \geq \gamma_{\text {Liquid }}$ (Zisman, 1964). Taking into consideration the coating procedure, the film-forming solution must be able to spread on the surface without draining. Therefore, the surface energy of the liquid should be lower than that of the substrate. In the case of metals, their surface energy is greater than that of the solution $\left(67.05 \mathrm{mN} \mathrm{m}^{-1}\right)$; while for the polymeric materials the surface energy of the liquid is greater than that of the solid, so it is guaranteed that the solution will remain on the surface.

\subsection{Mechanical properties}

\subsubsection{Peel strength analysis}

Once the films were obtained, their adhesion strength to the support was evaluated through a $180^{\circ}$ peel test. The values of the peak load, the average force developed during the detachment, and the resistance to take off are presented on Table 5.

Table 5. Peak Load, Average force, and Resistance to take off.

\begin{tabular}{cccc}
\hline Material & Peak Load $(\mathbf{N})$ & Average force $(\mathbf{N})$ & Resistance to take off $\left(\mathbf{N ~} \mathbf{c m}^{-1}\right)$ \\
\hline Aluminum & $0.19 \pm 0.05$ & $0.10 \pm 0.02$ & $0.04 \pm 0.004$ \\
\hline Steel & $021 \pm 0.04$ & $0.20 \pm 0.04$ & $0.08 \pm 0.002$ \\
\hline Sanitary rubber & $1.42 \pm 0.27$ & $1.32 \pm 0.38$ & $0.53 \pm 0.003$
\end{tabular}

The maximum adhesion strength should be obtained when the surface and the free energy of the materials adhered are equal (Pisanova \& Máder, 2000). According Slavutsky \& Bertuzzi (2015). Starch films present a surface tension of $52.48 \mathrm{mN} \mathrm{m}^{-1}$, with a polar component of $36.10 \mathrm{mN} \mathrm{m}^{-1}$, and a dispersive component of $16.38 \mathrm{mN} \mathrm{m}^{-1}$. According to these values and comparing with the surface energy of solids assessed, detachment should be spontaneous. Nevertheless, it is important to mention that the test could only be performed for aluminum, steel, and sanitary rubber samples where the film remained adhered to the support material.

These phenomena can be explained under the different adhesion theories. The case of the sanitary rubber responds to the mechanical interlocking model (Baldan, 2012). This theory states that adhesion between 
materials occurs at a macroscopic level and it is due to the roughness and porosity of the substrate. That is to say, the adhesion is a result of the mechanical keying of the liquid into the irregularities of the substrate surface. On the other hand, adhesion to the film to the metallic materials can be explained in terms of the electrostatic attraction theory (Baldan, 2012). This model is often applied in the case of incompatible materials such as polymers and metallic substrates. According to this theory, the interaction between the materials occurs due to a difference in electrostatic charges and the capability of the materials with a highly electrostatically charged surface to polarize other material surfaces.

The results indicated that the peak load reached while peeling the films off from the aluminum and steel test plates were similar and equal to a mean value of $0.20 \mathrm{~N}$, whereas the mean value of the average force required for detaching the film from the aluminum sample is the lowest. No significant difference is observed on the peak value. On the other hand, the values reported for the peak load and the average force during the detachment of the film from the sanitary rubber were $1.42 \mathrm{~N}$ and $1.32 \mathrm{~N}$, respectively, which indicates a greater adherence of the film to this surface that prevents the detachment.

When keeping the film samples poured and dried on aluminum and steel surfaces under relative humidity below $65 \%$, a spontaneous detachment was observed. During the drying process, the film can either detach spontaneously or adhere strongly to the surface. The first phenomenon can be attributed to the increment in starch concentration as the film dries, increasing the contact angle, generating a decrease in wettability along with the decrease in the work of adhesion and increase in the cohesion coefficient, causing the detachment of the film (Casariego et al., 2008). On the other hand, if the contact angle decreases when the film-forming solution is concentrated, the surface energy decreases and the work of adhesion increases. If there is a very high adhesion between the film and the substrate (belt surface), the film separation of the belt will be difficult (Han \& Gennadios, 2005).

The contact angle of film-forming solutions with concentrations of $0.5 \%, 1 \%, 3 \%$ and $5 \% \mathrm{w} / \mathrm{w}$ of starch on stainless steel specimens was determined to evaluate the effect of the increasing concentration of polysaccharide in the film-forming solution during the film drying. The results are presented in Figure 2 . We observed that the contact angle of the solution on the surface increases as the polysaccharide concentration increases, in accordance with what was previously stated.

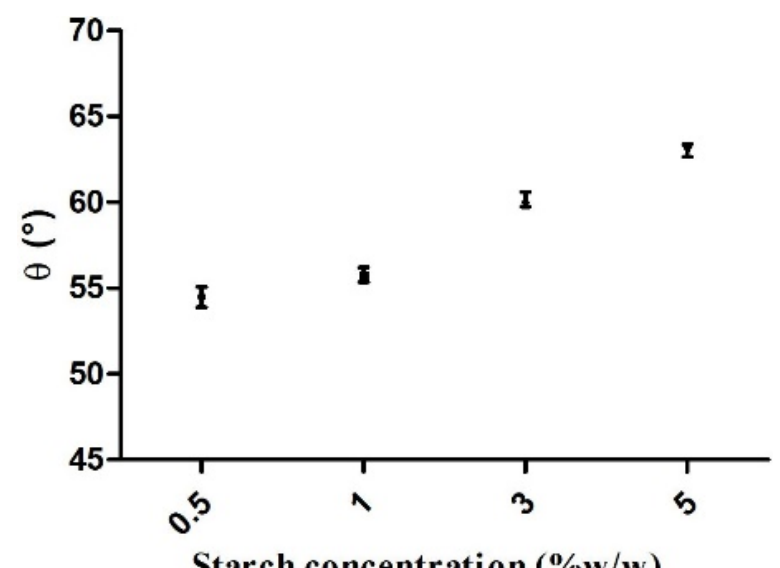

Starch concentration $(\% w / w)$

Figure 2. Contact angles of solutions of different starch concentrations on stainless steel.

\subsubsection{Tensile and tear resistance tests}

To compare the adhesion forces with the cohesion forces, mechanical tests were performed. In addition to tensile tests, tear resistance tests were performed. The data obtained for both assays, load versus distance, were plotted and are presented in Figure 3. 
During tensile tests (Figure 3a), the samples were subjected to an axial tension that increases until the failure of the specimen. From this test, it is possible to determine the resistance of the material to a force applied at a certain speed. On the other hand, the tear test measures the force required to continue tearing a specimen from an initial cut (Figure 3b). In the case of the trouser specimens, the opening of the initial cut occurs on the longitudinal axis of the specimen. Since the sample is subject to a tensile load, at the start of the tear a peak load is generated in which the material fails, then the effort required to finish the tearing of the sample is recorded.

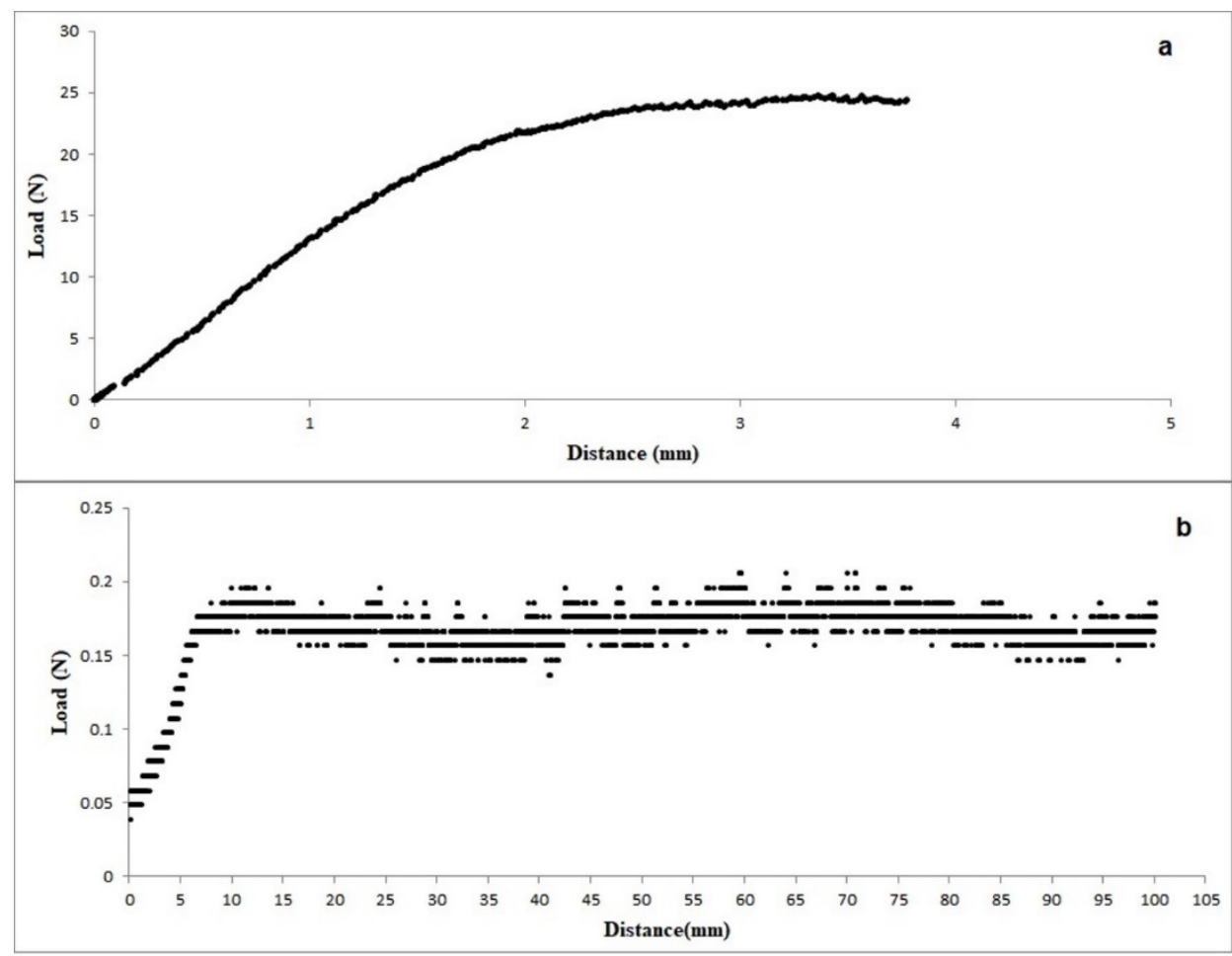

Figure 3. Load versus distance for (a) Tensile test; (b) Tear test.

Table 6 shows the values reported for the tear test such as the peak load, the average tear force, and the tear resistance.

Table 6. Values reported for mechanical tests.

\begin{tabular}{cccc}
\hline Tearing test & \multicolumn{2}{c}{ Tensile Strength Test } \\
\hline Peak load $(\mathbf{N})$ & $0.20 \pm 0.03$ & Maximum load $(\mathbf{N})$ & $23.48 \pm 2.88$ \\
\hline Average force(N) & $0.19 \pm 0.03$ & Elongation $(\mathbf{\%})$ & $7.25 \pm 0.61$ \\
\hline Tear resistance $\left(\mathbf{N ~ ~ c m ^ { - 1 } )}\right.$ & $19.83 \pm 2.41$ & Tensile Strength $(\mathbf{M P a})$ & $9.43 \pm 1.26$ \\
\hline
\end{tabular}

We observed that the peak load values for tearing and the average force value are very similar to the values obtained for the detachment of films from aluminum and stainless-steel surfaces (Table 5). It can be observed that the tear strength is higher than the resistance to take off. Furthermore, the maximum load required to break a film is higher than the loads needed to tear and peel the film. Therefore, it can be concluded that the film would not suffer mechanical damage when separated from the support. 


\section{Conclusion}

In the design of a coating system to obtain edible films, the operative conditions of the system, the mechanical details of the equipment, and the costs associated are of fundamental importance. Thus, during the selection of a suitable support material for the conveyor belt, several factors must be taken into consideration. The cost of the conveyor belt comprises an important percentage of the total investment in the equipment and on the other hand, the adequate selection of the material prevents the employment of an additional separate disposable substrate.

All the materials tested showed good performance under the operating conditions assayed to obtain edible films. The employment of metallic bands, in addition to being expensive, requires more demanding construction details than those corresponding to flexible belts. The TAC 36 (Teflon) support material has a low thickness that makes it difficult to obtain an endless band without discontinuities in the joint, and its cost is also high.

According to the work of adhesion values and the spreading coefficients obtained, the film-forming solution could be easily spread over metals and sanitary rubber followed by silicone and polyurethane belts. No difficulties were found when detaching the films from all the materials evaluated, except the case of the sanitary rubber, which showed high adhesion of the dry film under the test conditions. Considering the surface energy values of the materials analyzed, the polymeric belts are suitable for spreading the filmforming solution without spilling. Silicone and polyurethane belts resulted equally suitable as support materials. Finally, the CLINA 12UF polyurethane belt was chosen due to its convenient behavior and lower cost.

\section{References}

Alavi, S., Thomas, S., Sandeep, K. P., Kalarikkal, N., Varghese, J., \& Yaragalla, S. (2014). Polymers for packaging applications. Boca Raton: CRC Press. http://dx.doi.org/10.1201/b17388.

American Society for Testing and Materials - ASTM. (2010a). ASTM D903. West Conshohocken: ASTM International. American Society for Testing and Materials - ASTM. (2010b) ASTM D882. West Conshohocken: ASTM International.

Baldan, A. (2012). Adhesion phenomena in bonded joints. International Journal of Adhesion and Adhesives, 38, 95-116. http://dx.doi.org/10.1016/j.ijadhadh.2012.04.007

Bertuzzi, M. A., \& Slavutsky, A. M. (2016). Standard and new processing techniques used in the preparation of films and coatings at the lab level and scale-up. In M. Montero Garcia, M. Gómez-Guillén, M. López-Caballero \& G. Barbosa-Cánovas (Eds.), Edible films and coatings: Fundamentals and applications (pp. 21-42). Boca Raton: CRC Press.

Bierwagen, G. P. (1992). Film coating technologies and adhesion. Electrochimica Acta, 37(9), 1471-1478. http://dx.doi.org/10.1016/0013-4686(92)80092-Z

Casariego, A., Souza, B. W. S., Vicente, A. A., Teixeira, J. A., Cruz, L., \& Díaz, R. (2008). Chitosan coating surface properties as affected by plasticizer, surfactant and polymer concentrations in relation to the surface properties of tomato and carrot. Food Hydrocolloids, 22(8), 1452-1459. http://dx.doi.org/10.1016/j.foodhyd.2007.09.010

Della Volpe, C., \& Siboni, S. (1997). Some reflections on acid-base solid surface free energy theories. Journal of Colloid and Interface Science, 195(1), 121-136. PMid:9441613. http://dx.doi.org/10.1006/jcis.1997.5124

Ebnesajjad, S. (2012). Handbook of biopolymers and biodegradable plastics: Properties, processing and applications. Oxford: Elsevier. https://doi.org/10.1016/B978-012763952-9/50002-2.

Embuscado, M., Huber, K., \& Nieto, M. B. (2009). Edible films and coatings for food applications. New York: Springer. https://doi.org/10.1007/978-0-387-92824-1.

Erbil, H. Y., \& Meriç, R. A. (1988). Determination of surface free energy components of polymers from contact angle data using nonlinear programming methods. Colloids and Surfaces, 33, 85-97. http://dx.doi.org/10.1016/0166-6622(88)80051-9

Guilbert, S., \& Gontard, N. (2005). Agro-polymers for edible and biodegradable films: Review of agricultural polymeric materials, physical and mechanical characteristics. In J. H. Han (Ed.), Innovations in food packaging. Amsterdam: Academic Press. https://doi.org/10.1016/B978-012311632-1/50048-6.

Gutoff, E. B., \& Cohen, E. D. (2016). Water-and solvent-based coating technology. In J. R. Wagner Junior (Ed.), Multilayer flexible packaging (2nd ed.). San Diego: Elsevier. https://doi.org/10.1016/B978-0-323-37100-1.00014-4.

Han, J., \& Gennadios, A. (2005). Edible films and coatings: A review. In J. H. Han (Ed.), Innovations in food packaging. Amsterdam: Academic Press. https://doi.org/10.1016/B978-012311632-1/50047-4.

International Organization for Standardization - ISO. (2004). ISO 6383. Genebra: ISO. 
Mellinas, C., Valdés, A., Ramos, M., Burgos, N., Garrigos, M. D. C., \& Jiménez, A. (2016). Active edible films: Current state and future trends. Journal of Applied Polymer Science, 133(2), 42631. http://dx.doi.org/10.1002/app.42631

Pisanova, E., \& Máder, E. (2000). Acid-base interactions and covalent bonding at a fiber-matrix interface: Contribution to the work of adhesion and measured adhesion strength. Journal of Adhesion Science and Technology, 14(3), 415-436. http://dx.doi.org/10.1163/156856100742681

Rudawska, A., \& Jacniacka, E. (2018). Evaluating uncertainty of surface free energy measurement by the van Oss-ChaudhuryGood method. International Journal of Adhesion and Adhesives, 82, 139-145. http://dx.doi.org/10.1016/j.ijadhadh.2018.01.006

Skurtys, O., Velásquez, P., Henriquez, O., Matiacevich, S., Enrione, J., \& Osorio, F. (2011). Wetting behavior of chitosan solutions on blueberry epicarp with or without epicuticular waxes. Lebensmittel-Wissenschaft + Technologie, 44(6), 1449-1457. http://dx.doi.org/10.1016/j.Iwt.2011.02.007

Slavutsky, A. M., \& Bertuzzi, M. A. (2015). Formulation and characterization of nanolaminated starch based film. LebensmittelWissenschaft + Technologie, 61(2), 407-413. http://dx.doi.org/10.1016/j.Iwt.2014.12.034

Van Oss, C. J., Chaudhury, M. K., \& Good, R. J. (1988). Interfacial Lifshitz: Van der Waals and polar interactions in macroscopic systems. Chemical Reviews, 88(6), 927-941. http://dx.doi.org/10.1021/cr00088a006

Zisman, W. A. (1964). Relation of the equilibrium contact angle to liquid and solid constitution (pp. 1-51). Washington: American Chemical Society. https://doi.org/10.1021/ba-1964-0043.ch001.

Funding: Consejo de Investigación, Universidad Nacional de Salta - CIUNSa-Proyecto No 2260; Consejo Nacional de Investigaciones Científicas y Técnicas - PIP 2015 №

11220150100348. 